\title{
Improving Patient Satisfaction Based on Customer Satisfaction Index (CSI) Analysis in Natural Esthetic Clinic Makassar
}

\author{
Setya Haksama ${ }^{1}$ \\ Faculty of Public Health \\ Universitas Airlangga \\ Surabaya, Indonesia \\ E-mail: setyahaksama@fkm.unair.ac.id
}

\author{
Badai Septa Wahyudadi ${ }^{2}$ \\ Department of Dental Health \\ Polytechnic of Health \\ Makassar, Indonesia
}

\begin{abstract}
The opportunities and challenges of the health clinic business are enormous with extremely competitive levels, including oral and dental services at the Natural Esthetic Clinic (NEC) clinic of Makassar. It was necessary to measure the level of patient satisfaction with the services provided periodically. The purpose of this study was to measure perception and expectation to obtain patient satisfaction on dental services received based on Customer Satisfaction Index (CSI) using 5 qualities indicators such as Reliability, Assurance, Tangible, Emphaty, and Responsiveness (RATER).The results of the study were all satisfaction indicators in the "Very Satisfied" category, for GAP and CSI are indicators of reliability GAP $\mathbf{- 0 . 5 3}$ and CSI 87.43\%; indicator assurance GAP $-\mathbf{0 . 3 8}$ and CSI $90.85 \%$; tangible indicators GAP $\mathbf{- 0 . 2 8}$ and CSI $93.87 \%$; indicator emphaty GAP $-\mathbf{0 . 5 5}$ and CSI $86.79 \%$; and indicator responsiveness GAP $\mathbf{- 0 . 3 3}$ and CSI $92.17 \%$. Recommendation is to provide excellent service training to all dentists and dental nurses in providing services, improve service quality by adding various supporting facilities such as convenience of service space.
\end{abstract}

\section{Keywords - Service Quality; Reliability; Assurance; Tangible; Emphaty; Responsiveness; Satisfaction; Dental and Mouth Clinic}

\section{INTRODUCTION}

In the current openness era is a new business opportunity and challenge for health clinics to expand its market, but on the other hand it raises the increasingly tight competition among health clinics. The rapid economic growth and the challenges of the era of trade lead to increasingly tight competition in the business world, as well as business in health services, especially health clinics, which are required to meet the needs and desires of customers who are not just limited to the service alone ${ }^{[4]}$.

Dentist is one of the professions in the field of medicine involved and play an active role in realizing the goals of health development. Dentists provide services in the form of dental care to patients with dental health problems. The existence of dentists in various cities in Indonesia also provide services and help the community in dental health problems.
Patients who wish to obtain dental services can obtain directly by visiting hospitals or puskesmas provided by the government in various parts of Indonesia ${ }^{[14]}$.

Patient satisfaction is the level of a person's feelings after comparing the performance of the product or the perceived results of the patient with his expectations [20]. With consumers satisfied with a long-term use, consumers' sense of satisfaction will affect actions based on past experiences where they will not be able to move easily because of marketing stimulation ${ }^{[3,12]}$.

This study measured the level of community satisfaction on dental health services received by the community in Natural Esthetic Clinic Makassar (NEC Makassar) based on patient perception and expectation that the result is used as material of development, innovation effort, and continuous improvement of service quality so that service can be created prime $^{[11,13]}$.

The type of research used survey method with cross sectional study approach where data related to reliability, realibility, assurance, tangible, empathy or emphaty, responsiveness or abbreviated as RATER, and variable of patient satisfaction taken at the same time ${ }^{[6,10]}$. This research was conducted in NEC Makassar which is one of dental practice clinic from February to March 2015. Description of research variables are as follows:

1. Dental health service quality indicator is all services provided by doctors and dental nurses that can provide satisfaction to patients treated, where indicator of service quality is characteristic such as reliability, assurance, tangible, emphaty, and responsiveness.

a. Reliability (realibility) is the ability to provide immediate and satisfactory service to patients, as well as in accordance with the promise of doctors and dental nurses. Reliability indicators include speed of service process and fair (no favoritism);

b. Assurance, including the ability, courtesy and credibility of the doctors/ staff, free of danger, risk or 
doubt. The indicators consist of service warranty and legal certainty in the service.

c. Physical evidence (tangible), including physical facilities, equipment, employees and facilities in dentist clinic practice that can provide patient satisfaction. The indicators include equipment and equipment, ease of service and personnel.

d. Concern or empathy (empathy), which includes the ease of doing relationships, good communication, and sincere attention to the needs of patients. The indicators include ease of contact/ communication, respect for the patient, attention to the patient and honesty;

e. Responsiveness is the ability of dentists and nursing staff to provide prompt and agile service to patients requiring dental services. The indicator is the awareness of providing services and mastering the task/ job.

2. Patient satisfaction is a product or service that is able to provide something sought by consumers to the level enough and consumers assess that the product or service has provided a level of enjoyment in which the level of fulfillment is more or less.

\section{RESEARCH METHODS}

The study population was all patients or visitors who came to NEC Makassar to get dental and mouth health services. The sample size is 74 respondents. The research design is cross sectional with where the respondent is taken at a certain time to get picture about hope and satisfaction of patient who visit NEC Makassar based on Customer Satiscaftion Index.

\section{Survey Instrument}

Survey instrument used questionnaire guidance that have been developed in such a way that can be obtained information about the Customer Satisfaction Index composed of five quality indicators consisting of Reliability, Assurance, Tangible, Emphaty, and Responsivenss or often abbreviated with RATER.The definition of each RATER indicator explains as follows ${ }^{[10,21,22]}$ :

1. Reliability is the ability to perform services or services promised with reliable and accurate.

2. Assurance (guarantee or certainty), is related to knowledge, courtesy, the ability of employees in raising the trust and confidence of its customers.

3. Tangible (exposed or manifested), is something that can be seen in the form of physical facilities, equipment, employees, environmental conditions, and others that can be captured by the eye and can be remembered by the customer.

4. Empathy (having a sense of caring) is a concern raised by giving personal attention to customers.
5. Responsiveness is the availability to providing assistance to customers quickly and sincerely.

\section{Data Analysis Technique}

Data analysis technique was done to obtain various information and process of data analysis ${ }^{[15]}$. The process includes the process of data editing done to ensure and check the completeness of the contents of the questionnaire that has been filled. Followed by the process of coding and data entry. In the above steps was also done data cleaning mechanism (cleaning data) which is a process about:

1. Check the completed questionnaire to ensure that the questionnaire has been filled in sufficiently and answered correctly and in accordance with the scope of the survey objectives.

2. Implement corrections when necessary, and discard incomplete answers.

Data analysis uses Service Quality technique, where in service quality technique is a method used to analyze gap (difference) between expected service (expectation) with customer perceived service (perception) to get value of Customer Satisfaction Index. The values given by the respondents are divided into each of the five categories (based on the Likert scale), namely:

1. Perception Level: Very Dissatisfied (value 1), Not Satisfied (value 2), Neutral (value 3), Satisfied (value 4), Very Satisfied (value 5).

2. Expectation Level: Very Unexpected (value 1), Not Expect (value 2), Neutral (value 3), Expect (value 4), Very Expect (value 5).

Furthermore, the average value obtained from each attribute of satisfaction level according to the perspective of the patient or visitor, divided by the average attribute value of each respondent's value, obtained by the value of Customer Satisfaction Index (CSI), which shows how much the patient's expectation the services needed to satisfy the respondents ${ }^{[22]}$. The CSI score is as follows: $<40.00=$ "Very Unsatisfied" category; $>40.00-55.00=$ "Not Satisfied" category; > 55.00 70.00 = Category "Enough"; > $70.00-85.00=$ "Satisfied" category; and $>85.00-100.00=$ "Very Satisfied" category $[20,22]$.

GAP analysis method is a method used to determine the difference between the perception level with the expectation of respondents to the aspect of services provided Natural Esthetic Clinic Makassar. Given the difference in value, it can be known and can be used as reference materials and clinical considerations to fix, improve management systems, and improve the quality of service.

Based on a 5 point Likert scale, the difference or gap between perception (level of satisfaction or reality) and expectations (level of importance or expectation) is measured by perception-expectation gap (P-E gap) ${ }^{[21,22]}$, so if: 
1. P-E gap has a value of 0 (zero) means there is no difference between customer expectation (CE) and customer perception (CP) against service quality (SQ).

2. If $\mathrm{CP}-\mathrm{CE}<0$, then the customer's expectation exceeds the customer's perception of the service provided by the service provider.

3. If $\mathrm{CP}-\mathrm{CE}>0$, means the performance of the service provider exceeds the customer's expectations ${ }^{[10,17]}$.

\section{RESULT AND DISCUSSION}

Based on the data of patient respondent characteristics, it was found that from female gender equal to $56.8 \%$ and men seebsar $43.2 \%$. While patients aged less 20 years by $6.8 \%$; 20 29 years as many as $27.2 \%$; 30-39 years occupy the largest portion of service users in NEC Makassar by $39.2 \%$; then patients aged 40-49 years and over 49 years each $13.5 \%$. Based on the level of education, the composition of junior high school education is $9.5 \%$; high school graduates $32.4 \%$; followed by level of academy (D3 / D4) as much as 27.0\%; strata-1 of $18.9 \%$; and Strata-2 by $12.2 \%$. For the job setting, the largest portion of clinical practice patients were civil servants (37.8\%), then entrepreneurs $(23.0 \%)$, private employees (16.2\%), TNI / Polri (14.9\%), students (5.4\%) and others $(2.7 \%)$. From the background information of patients who use services in NEC Makassar are women or men who have age between 20-39 years, graduate from high school to college, and have jobs and regular income.

The results of perceptual measurements and expectations of patients or visitors at the Natural Esthetic Clinic Makassar were described below as follows:

\section{Reliability Indicator}

The reliability indicators are 4 questions that are arranged to analyze the gap between perception and expectations seen as follows

TABLE 1. RELIABILITY INDICATOR IN NATURAL ESTHETIC CLINIC MAKASSAR

\begin{tabular}{|c|c|c|c|c|}
\hline No & Reliability Indicators & Perception & Expectation & GAP \\
\hline 1 & Ability in Provide Services & 3.86 & 4.22 & -0.36 \\
\hline 2 & $\begin{array}{l}\text { Giving Services Fixed with } \\
\text { Promises }\end{array}$ & 3.65 & 4.30 & -0.65 \\
\hline 3 & $\begin{array}{l}\text { Speed of Process in } \\
\text { Services }\end{array}$ & 3.62 & 4.26 & -0.64 \\
\hline \multirow[t]{2}{*}{4} & Fairness in Services & 3.68 & 4.16 & -0.48 \\
\hline & Average (Mean) & 3.70 & 4.24 & \\
\hline & $\begin{array}{r}\text { GAP = } \\
\text { (Mean Perception - } \\
\text { Mean Expectation })\end{array}$ & & & -0.53 \\
\hline & $\begin{array}{l}\text { S Index }=(\text { Mean Perception/ } \\
\text { Mean Expectation }) \times 100 \%\end{array}$ & & & 87.43 \\
\hline
\end{tabular}

The reliability indicators as shown in Table 1 show that the gap between expectation and service perception in Natural Esthetic Clinic (NEC) Makassar shows the number of -0.53 . While CSI (Customer Satisfaction Index) shows the number of $87.43 \%$ belong to the category of "Very Satisfied". The results above show that patients visiting NEC Makassar feel there is a GAP between expectations and perceptions received from services provided on indicators of reliability even though the category is Very Satisfied.

The highest reliability indicator with GAP is on items about the promised service getting a GAP value of -0.65 . This should be a major concern as it relates to the services provided. It takes great effort for all health workers who provide services so that patients or visitors can provide good value. Because if not paid attention can reduce the visit to NEC Makassar clinic. Reliability was related to the ability of the organization to provide accurate service since the first time without making any mistakes and delivering his services in accordance with the agreed time ${ }^{[18]}$.

The success of an organization depends heavily on the knowledge, skills, creativity, motivation, and organizational background of the organization ${ }^{[5]}$. Therefore, the management of NEC Makassar need to pay attention to the reliability aspect of its employees. In the implementation of the process of health services, both medical and non-medical must be reliable. NEC Makassar still has some obstacles in implementing health service process, so that indicator of reliability need to be improved.

\section{Assurance Indicators}

Assurance indicators were 4 questions that are developed to analyze the gap between perception and expectation that are seen as follows.

TABLE 2. ASSURANCE INDICATOR IN NATURAL ESTHETIC CLINIC MAKASSAR

\begin{tabular}{|r|l|c|c|c|}
\hline No & \multicolumn{1}{|c|}{ Assurance Indicators } & Perception & Expectation & GAP \\
\hline 1 & Doctor's Personality Can Be Trusted & 3.62 & 4.03 & -0.41 \\
\hline 2 & $\begin{array}{l}\text { Free from the risks and doubts of the } \\
\text { Service }\end{array}$ & 3.84 & 4.12 & -0.28 \\
\hline 3 & Guarantee of Provision of Services & 3.78 & 4.15 & -0.37 \\
\hline 4 & Services in legal aspect & 3.65 & 4.09 & -0.44 \\
\hline Average (Mean) & $\mathbf{3 . 7 2}$ & $\mathbf{4 . 1 0}$ & \\
\hline $\begin{array}{l}\text { GAP = (Mean Perception - Mean } \\
\text { Expectation) }\end{array}$ & & $\mathbf{0 . 3 8}$ \\
\hline $\begin{array}{l}\text { CS Index }=(M e a n \text { Perception/ Mean } \\
\text { Expectation) } \mathbf{~ 1 0 0 \% ~}\end{array}$ & \multicolumn{3}{|c}{ Source: Primary Data } \\
\hline
\end{tabular}

The assurance indicators as shown in Table 2 show the gap between expectation and service perception in Natural Esthetic Clinic (NEC) Makassar showing the number of -0.38. While the CSI (Customer Satisfaction Index) shows the figure of $90.85 \%$ belong to the category of "Very Satisfied".

In the table above, the largest GAP indicator with a value of -0.44 was related to legal certainty in the service. This has the meaning that in providing clinical services NEC Makassar need to provide assurance of legal certainty associated with the services provided. One of the efforts that should be 
executed by preparing the standard of service procedure what was then explained to the patient related to the SOP.

Assurance was a behavior of officers who are able to grow consumer confidence in the organization and can create a sense of security for patients. Assurance also means that service providers are always polite, and master the knowledge and skills required to handle any customer questions or concerns ${ }^{[10]}$. Basically, the assurance indicator is a reflection on the guarantee that can be given by NEC Makassar to its employees in order to support the excellent service that will be given to the patient. If employees feel they have been able to provide appropriate assurance to support excellent service, patients will be confident and trust when getting dental and oral health services at NEC Makassar.

\section{Tangible Indicator}

Tangible indicators are 4 questions that are arranged to analyze the gap between perception and expectations seen as follows

TABLE 3. TANGIBLE INDICATORS IN NATURAL ESTHETIC CLINIC MAKASSAR

\begin{tabular}{|r|l|c|c|c|}
\hline No & \multicolumn{1}{|c|}{ Tangible Indicators } & Perception & Expectation & GAP \\
\hline 1 & $\begin{array}{l}\text { Physical Facilities \& } \\
\text { Equipment are Complete }\end{array}$ & 3.88 & 4.19 & -0.31 \\
\hline 2 & $\begin{array}{l}\text { Employees are always } \\
\text { Neat, Clean, \& Uniformed }\end{array}$ & 3.78 & 4.14 & -0.36 \\
\hline 3 & $\begin{array}{l}\text { The Clinic Room is } \\
\text { Comfortable and Clean }\end{array}$ & 3.95 & 4.26 & -0.31 \\
\hline 4 & Ease of Services & 4.04 & 4.19 & -0.15 \\
\hline Average (Mean) & $\mathbf{3 . 9 1}$ & $\mathbf{4 . 2 0}$ & $\mathbf{- 0 . 2 8}$ \\
\hline $\begin{array}{l}\text { GAP = (Mean Perception - } \\
\text { Mean Expectation) }\end{array}$ & & \multicolumn{3}{|c|}{ Source: Primary Data } \\
\hline $\begin{array}{l}\text { CS Index = (Mean Perception/ } \\
\text { Mean Expectation) x 100\% }\end{array}$ & \multicolumn{3}{|c|}{} \\
\hline
\end{tabular}

Based on Table 3, the gap between expectation and perception of tangible indicator service in Natural Esthetic Clinic Makassar shows the number of -0.28 . While CSI (Customer Satisfaction Index) shows the number of $93.27 \%$ belong to the category of "Very Satisfied".

The biggest GAP of the tangible indicator is that the service provider's item is always neat, clean and uniformed 0.36 . This indicates that the service providers are not wellgroomed, clean and uniformed. Therefore, the management of NEC Makassar need to immediately clean up by providing a good uniform, neat, and clean each day so that patients or visitors will judge both these items. The tangible indicator is defined as an indicator of physical shape, service, facilities, human resources, and others in NEC Makassar that can be seen and perceived by the five senses.

Thus, NEC Makassar needs to organize physical form, improve service, give uniform to all its employees so that patients can easily see and give an assessment on the condition. This is in accordance that physical evidence (tangible) was related to the attractiveness of physical facilities, equipment or equipment, and materials used by the organization in a complete, clean and well-ordered condition as well as the appearance of the service provider that is neat [1].

\section{Emphaty indicator}

Emphaty indicator there are 4 questions that are arranged to analyze the gap between perception and expectation seen as follows

TABLE 4. EMPHATY INDICATORS IN NATURAL ESTHETIC CLINIC MAKASSAR

\begin{tabular}{|r|l|c|c|c|}
\hline No & \multicolumn{1}{|c|}{ Emphaty Indicators } & Perception & Expectation & GAP \\
\hline 1 & Ease of Communication & 3.68 & 4.15 & -0.47 \\
\hline 2 & Always Giving Attention & 3.51 & 4.20 & -0.69 \\
\hline 3 & Respect to The Patients & 3.61 & 4.20 & -0.59 \\
\hline 4 & $\begin{array}{l}\text { Pay Attention to Patients } \\
\text { Condition }\end{array}$ & 3.72 & 4.18 & -0.46 \\
\hline Average (Mean) & $\mathbf{3 . 6 3}$ & $\mathbf{4 . 1 8}$ & $\mathbf{- 0 . 5 5}$ \\
\hline $\begin{array}{l}\text { GAP = (Mean Perception - Mean } \\
\text { Expectation) }\end{array}$ & & & $\mathbf{8 6 . 7 9}$ \\
\hline $\begin{array}{l}\text { CS Index = (Mean Perception/ Mean } \\
\text { Expectation) } \mathbf{~ 1 0 0 \% ~}\end{array}$ & & \multicolumn{3}{|c}{ Source: Primary Data } \\
\hline
\end{tabular}

Based on Table 4 above, the gap between expectation and service indicator empathy in Natural Esthetic Clinic Makassar shows the number of -0.55 . While CSI (Customer Satisfaction Index) shows the number of $86.79 \%$ belong to the category of "Very Satisfied".

The biggest GAP item is always paying attention to patients with a value of -0.69 is a very large GAP. This should be the main concern and care of the management of NEC Makassar, because if not repaired and upgraded can reduce patient visits to NEC Makassar clinic.

It was states that emphaty is the level of understanding that the service provider's organization has for the problems faced by its customers and acts in the interests of consumers and gives personal attention to consumers and has a comfort of operating hours ${ }^{[2,18,19]}$.

\section{Responsiveness indicator}

Responsiveness indicators are 4 questions that are arranged to analyze the perceptual differences and expectations seen as follows 
TABLE 5. INDICATORS OF RESPONSIVENESS IN NATURAL ESTHETIC CLINIC MAKASSAR

\begin{tabular}{|c|c|c|c|c|}
\hline No & $\begin{array}{l}\text { Responsiveness } \\
\text { Indicators }\end{array}$ & Perception & Expectation & $\overline{\text { GAP }}$ \\
\hline 1 & $\begin{array}{c}\text { Immediately to Provide } \\
\text { Services }\end{array}$ & 3.88 & 4.19 & -0.31 \\
\hline 2 & $\begin{array}{l}\text { Mastery of Duty in } \\
\text { Services }\end{array}$ & 3.78 & 4.32 & -0.54 \\
\hline 3 & $\begin{array}{l}\text { Have Authority to Decide } \\
\text { Services }\end{array}$ & 3.95 & 4.20 & -0.25 \\
\hline 4 & $\begin{array}{l}\text { Always Responsibly in } \\
\text { The Services }\end{array}$ & 4.04 & 4.27 & -0.23 \\
\hline & Average (Mean) & 3.91 & 4.25 & \\
\hline & $\begin{array}{l}\mathbf{P}=(\text { Mean Perception }- \\
\text { Mean Expectation })\end{array}$ & \multicolumn{3}{|c|}{-0.33} \\
\hline & $\begin{array}{l}\text { ndex }=(\text { Mean Perception/ } \\
\text { an Expectation }) \text { x } 100 \%\end{array}$ & \multicolumn{3}{|c|}{92.17} \\
\hline
\end{tabular}

Based on Table 5 above, the level of gap between expectations and service perception of responsiveness indicator in Natural Esthetic Clinic Makassar shows the number of -0.33 . While CSI (Customer Satisfaction Index) shows the number of $92.17 \%$ belong to the category of "Very Satisfied".

The largest GAP on this indicator is a weak mastery of duties with a value of -0.54 . The task mastery needs to be considered carefully because it is related to service responsiveness. The less mastered the longer the service will be.

Responsiveness is related to the willingness and ability of the officers to assist consumers and respond to their requests, as well as to inform when services will be provided and then provide services quickly and accurately ${ }^{[16]}$. Therefore responsiveness needs to be given immediately with the improvement of the ability of the officers at the NEC Makassar clinic.

Based on the descriptions of the above research results obtained gap value (GAP) between perceptions and expectations of patients on services in NEC Makassar obtained values as follows:

TABLE 6. RATER INDICATOR IN NATURAL ESTHETIC CLINIC (NEC) MAKASSAR

\begin{tabular}{|r|l|r|r|r|r|}
\hline No & Indikator & Perception & Expectation & GAP & $\begin{array}{c}\text { CSI } \\
(\mathbf{\%})\end{array}$ \\
\hline 1 & Reliability & 3.70 & 4.24 & -0.53 & 87.43 \\
\hline 2 & Assurance & 3.72 & 4.10 & -0.38 & 90.85 \\
\hline 3 & Tangible & 3.91 & 4.20 & -0.28 & 93.87 \\
\hline 4 & Emphaty & 3.63 & 4.18 & -0.55 & 86.79 \\
\hline 5 & Responsiveness & 3.91 & 4.25 & -0.33 & 92.17 \\
\hline
\end{tabular}

It is seen that the indicator with the greatest GAP value between perception and expectation is the indicator empathat where the lowest perception value 3.63 and the expectation of
4.18 obtained the difference seebsar -0.55 . The value of SCI indicator emphaty is also lowest with $86.79 \%$. Therefore it was worth nothing carefully by the management of NEC Makassar on indicator emphaty to be a top priority in efforts to improve the quality of service. It is important and the main dentists and dental nurses need to improve and show empathy well for example to feel if the patient experienced very pain in his teeth by giving the attitude of feeling pain and entertaining.

In research showed on some aspects that affect performance, human resources focus is the most powerful aspect to prove the relationship with performance ${ }^{[7]}$. Therefore in the work needs to be improved ability.

In the current era of dental and oral clinic services increasingly competent, so patient satisfaction is one of the indicators that can provide information that a type of service has been able to meet the expected patient of the service. Patient satisfaction depends on the ability of providers to meet consumer desires, and no matter how good the quality of service provided by the provider, consumers will always want to get better service ${ }^{[9]}$. Patient satisfaction is assessed based on various factors other than the service delivery process. Patient satisfaction judgments always rely heavily on their past experiences ${ }^{[8]}$.

Patients who use dental services from clinics tend to utilize dental clinic services because of health problems, experience of treatment services as old customers, and satisfaction perceptions that have been able to meet their expectations in health services. This makes the loyalty of patients to use dental and oral health services at NEC Makassar good. Customer satisfaction can provide many benefits including: 1). Customer or patient loyalty will increase; 2). Increase revenue from transactions or repeat purchases; 3 ). Suppressing future customer transaction costs such as communications, marketing, sales and customer service costs; 4). Increasing price tolerance, especially customer willingness to pay premium prices and customers are less likely to be tempted to move elsewhere; 5). Growing positive contagious recommendations; 6). Increase organization's bargaining power to business partners, suppliers and more ${ }^{[18,20]}$.

\section{CONCLUSIONS AND RECOMMENDATIONS}

Based on the results of the study showed that the level of perception and expectation of patients treated at NEC Makassar is in the category of Very Satisfied. For the greatest GAP value is emphaty of -0.55 with CSI $86.79 \%$, and the smallest is tangible at -0.28 with CSI $93.87 \%$.

Suggestions that can be done is to improve the interior, facilities, and services; and provide training for all employees including doctors in service excellence, and increase attention to all pain complaints suffered by the patient by feeling the suffered by the patient. 


\section{REFERENCE}

1. Bitner, MJ; and Zeithaml, VA. 2003. Service Marketing ( ${ }^{\text {rd }}$ ed.), Tata Mc Graw Hill, New Delhi.

2. Dehghan, A. 2006. Relationship between Service Quality and Customer Satisfaction, Thesis. Luella University of Technology.

3. Kotler, P. 2000. Marketing Management. Indonesian edition, Translated: H. Teguh, Ronny dan B. Molan (eds). PT Indeks. Jakarta.

4. Kuntjoro, T. and ASH. Purwanto, 2005. Studi Kasus Restrukturisasi Dinas Kesehatan Kabupaten Rembang dengan Pembentukan Cabang Dinas dan Pusat Kesehatan Desa. Jurnal Manajemen Pelayanan Kesehatan, 08(04): 199-205

5. Lovelock; Christopher, 2004, Service Marketing and Management, New Jersey: Prentice Hall.

6. Marsuli; AG. Mukti; and A. Utarini. 2005. Mutu Pelayanan Pasien Peserta Askes dan Umum di Instalasi Rawat jalan RSUD Dr. M. Yunus Provinsi.

7. Martineau T. and J. Buchan, 2000. Human Resources and The Success of Health Sector Reform. Makalah, dipresentasikan pada $128^{\text {th }}$ Annual Meeting of the American Public Health Association, Boston, 12-16 November 2000

8. Oliver, RL. 1980. A Cognitive Model of the Antecedents and Consequences of Satisfaction. Journal of Marketing Research. Vol. XVII. November 1980. 460-9.

9. Padma, Panchapakesan; Chandrasekharan R; L. Prakash Sai. 2009. A Conceptual Framework of Service Quality in Healthcare: Perspective of Indian Patients And Their Attendants. Benchmarking: An International Journal. http://www.emerald insight.com/1463-5771.htm

10. Parasuraman, A; and Valarie. 2001. A Conceptual Model of Service Quality and Implication for Future Research. Journal of Marketing. Vol. 49, pp. 41-50.

11. Picket, G. and John, JH. 1995, Kesehatan Masyarakat: Administrasi dan Praktik, Edisi 9, 464, diterjemahkan oleh: Prof. Dr. Ali Ghufron Mukti, M.Sc., PhD. EGC, Jakarta.
12. Purnama, N. 2006. Manajemen Kualitas Perspektif Global. Edisi Pertama, Cetakan Pertama. Ekonisia Kampus, Fakultas Ekonomi UII. Yogyakarta.

13. Rachmawati, IK. 2004. Manajemen, Konsep-konsep Dasar dan Pengantar Teori. Cetakan ke-1. UMM Press. Malang, 280 hal.

14. Rahmulyono, A. 2007. Analisis Pengaruh Kualitas Pelayanan terhadap Kepuasan pasien Puskesmas. Skripsi, tidak dipublikasikan. Fakultas Ekonomi, Universitas Islam Indonesia. Yogyakarta.

15. Santosa, PB; and Ashari. 2005. Analisis Statistik dengan Microsoft Excel dan SPSS. Andi Offset, Yogyakarta.

16. Sriwong, B. 2004. Application of Quality Gap Model to Measure the Quality of Pharmacist Service in Retail Pharmacy Setings: An Examination of Expectation and Perception. Thai Journal of Pharmacy Vol.1.

17. Tjiptono, F; and Candra, Gregorius. 2007. Service, Quality Satisfaction. Yogyakarta: Penerbit Andi.

18. Tjiptono, F. 2012. Service Management: Mewujudkan Layanan Prima. Yogyakarta: Penerbit Andi.

19. Venetis, Karin A and Pervez N. Ghauri, 2004. Service Quality and Customer Retention: Building Longterm Relationships. European Journal of Marketing, Vol. 38, No.11/12, pp. 1577-1598.

20. Yamit, Z. 2005. Manajemen Kualitas Produk dan Jasa. Edisi Pertama, Cetakan Keempat. Ekonisia Kampus, Fakultas Ekonomi UII Yogyakarta.

21. Zeithaml, VA. 1988. Consumer Perception of Price, Quality, and Value: a Meansend Model and Synthesis of Evidence. Journal of Marketing. 52, pp.2-11

22. Zeithaml, AA; Parasuraman; and Leonard L. Berry. 1988. SERVQUAL: A Multiple-Item Scale for Measuring Customer Perceptions of Service Quality. Journal of Retailing, 64, pp. 12-23. 